\section{An Investigation of Trait Prioritization in Rosaceous Fruit Breeding Programs}

\author{
R. Karina Gallardo ${ }^{1,7}$ \\ School of Economic Sciences, Tree Fruit Research and Extension Center, \\ Washington State University, 1100 N. Western Avenue Wenatchee, WA \\ 98801
}

\author{
Diem Nguyen ${ }^{2}$ and Vicki McCracken ${ }^{3}$ \\ School of Economic Sciences, Washington State University, P.O. Box 646210, \\ Hulbert Hall 101, Pullman, WA 99164
}

\author{
Chengyan Yue ${ }^{4}$ \\ Department of Horticultural Science and Department of Applied Economics, \\ University of Minnesota, 1970 Folwell Avenue, St. Paul, MN 55108
}

James Luby ${ }^{5}$

Department of Horticultural Science, University of Minnesota, Twin Cities, 1970 Folwell Avenue, St. Paul, MN 55108

\section{James R. McFerson ${ }^{6}$ \\ Washington Tree Fruit Research Commission, 1719 Springwater Avenue, Wenatchee, WA 98801}

Additional index words. rosaceous fruit, breeding programs, Tobit model

\begin{abstract}
Over 60 rosaceous crop breeding programs exist in North America, but no information has been available on which traits are targeted for selection or how breeders make such decisions. We surveyed all active rosaceous fruit breeding programs in the United States and Canada to determine: 1) the relative importance of over 50 plant traits that breeders select for 2) the likelihood of selection for the most important traits; and 3) the factors influencing breeders' decisions. A double-bounded Tobit model was used to investigate the effect of supply chain parties, technical and socioeconomic challenges, and crop characteristics on the likelihood of selection for trait clusters. We found that consumer-driven forces positively impact the likelihood of selection for traits more than producer forces and a breeder's own experience. Technical factors are as important as socioeconomic factors but less important than market-related factors. Our findings provide the first ever evidence that a socioeconomic approach in specialty crop breeding programs can contribute to an improved understanding of the effects of different supply chain factors on breeding programs' trait priority setting.
\end{abstract}

Innovation though development and commercialization of new cultivars has become an increasingly important strategy to enhance economic sustainability of U.S. specialty crop industries, including those producing and processing rosaceous crops. This botanical family is of considerable economic importance and includes a range of crops with diverse end

Received for publication 2 Feb. 2012. Accepted for publication 18 Apr. 2012

This work was partially funded by USDA's National Institute of Food and Agriculture Specialty Crop Research Initiative project, ${ }^{3}$ RosBREED: Enabling marker-assisted breeding in Rosaceae ${ }^{2}$ (2009-51181-05808).

${ }^{1}$ Assistant Professor, Extension Specialist.

${ }^{2}$ Former Post-Doctoral Research Associate.

${ }^{3}$ Professor and Associate Director.

${ }^{4}$ Assistant Professor, Bachman Endowed Chair in Horticultural Marketing.

${ }^{5}$ Professor.

${ }^{6}$ Manager.

${ }^{7}$ To whom reprint requests should be addressed; e-mail karina_gallardo@wsu.edu. selection targets or whether a strategic approach using socioeconomic analysis of trait values would provide analytical insight. It seems likely that breeders establish priorities based primarily on their experience, insights, and interaction with their direct stakeholderscrop producers. However, no scientific literature or even non-technical studies exist to assess the validity of this view. To successfully anticipate demand and provide the marketplace with desirable and innovative cultivars for the fresh or processing market, it would seem breeding programs should be linked with all relevant supply chain parties, including consumers. However, we do not know these priorities and they may in fact be in conflict, which could create a most difficult challenge to breeders when setting program priorities.

Genetic and genomic technologies applicable to rosaceous breeding have improved considerably over recent decades (Brown, 2003). The use of DNA information and techniques like marker-assisted breeding (MAB) can potentially make breeding programs more efficient in the use of financial, human, and time resources (Alpuerto et al., 2009; Luby and Shaw, 2001). In MAB, mating and selection decisions are informed both by the observable parental traits (their phenotypes) and by genetic knowledge of the DNA information they carry (their genotypes). However, because implementing this technology requires substantial knowledge and investment in human and physical resources, it is most gainfully applied to high-priority traits. Thus, when determining the target traits for a breeding program, it would be advantageous to identify and account for all supply chain parties: growers, packers, processors, marketers, and consumers.

The objective of this study is to understand how rosaceous crop breeders evaluate the importance of traits and what factors, including interested parties in the supply chain, significantly influence the likelihood of selection for each trait in their breeding programs. This information will also provide a baseline for a larger study to compare priorities assigned by rosaceous crop breeders and by supply chain parties.

There is scant literature relevant to this area of inquiry. Frey (1996) conducted a survey to assess the size of public and private plant breeding programs in the United States. He found that a total of 2241 science personyears were devoted to plant breeding with $66 \%$ working for private companies, $24 \%$ for state and agricultural experiment stations, and $10 \%$ for the U.S. Department of Agriculture. Frey (1996) also determined that $40 \%$ of all science person-years were devoted to grain crops compared with $15 \%$ for temperate fruits, vegetables, and nut crops. Fuglie and Walker (2001) used the data from Frey's survey to investigate the factors influencing the level of public and private breeding research. They found that investment in the private sector breeding was positively affected by the value of the crops and negatively affected by the costs in varietal development. Of the studies reviewed, only one 
study focused on plant breeding priorities and resource allocation in specific breeding programs. Fuji et al. (2007) investigated ing programs. They found that priorities have shifted to product characteristics with rising relative returns to producers, i.e., wheat protein content, rather than productivity. Given this nearly complete lack of information in the literature, in 2010, we conducted a comprehensive survey of all known rosaceous breeders in the United States and Canada.

This article is organized in three sections: (1) methods, including data description and econometric model; (2) results and discussion, including a description of the breeding programs surveyed, relative importance of traits, likelihood of selecting trait clusters, and major findings; and (3) conclusions.

\section{Methods}

Data description. During April to June of 2010, we conducted a comprehensive internet survey of 60 rosaceous breeding programs, which is, to our knowledge, the entire population of these programs in the United States and Canada. We obtained 40 responses; however, five were incomplete and not considered in the analysis, reducing the sample size to 35 complete responses, equivalent to a $58 \%$ response rate. These complete responses correspond to rosaceous breeding programs whose target crops are apple scion and rootstock, apricot scion, cherry scion (sweet and tart), peach scion, pear scion, blackberry, red raspberry, strawberry, and rose. To reduce complexity, we focused our analysis on fruit scion breeding programs and did not consider programs addressing rootstock (one response) and rose (two responses). This reduced the total number of responses to 32. Furthermore, because of the small number of breeding programs having as the main crop apricot, blackberry, cherry, and pear, we focused on crops with sufficient observations to yield meaningful results. This reduced the sample size used in this study to 24 responses, representing eight programs in strawberry, eight in peach, four in apple, and four in red raspberry. Table 1 lists all programs contacted, programs responding to the survey, and programs whose responses were used in this study.

The survey was divided into three sections. A copy of the survey is available on request. breeding priorities in Japanese wheat breed-

The first section included questions about background information of the breeding program, including: main crop bred, main use of the target crop (fresh or processed market), years of experience of the breeder leading the program, program characteristics (e.g., number of cultivars to be released, use of MAB), and program location (Pacific Northwest, CA, Midwest, Northeast, Southeast, and Canada). The second section contained questions about considerations influencing priorities when selecting a trait for inclusion in the breeding program. Breeders were asked to rate on a 0 to 10 scale $(0=$ very unimportant, $10=$ very important) the importance of a range of factors on their decisions, including: nursery industry, producers, marketers, wholesalers, retailers, consumers, and funding agency needs/preferences, breeder's own experience, experience of other colleagues, intended use of the crop, and available premiums. In this section, breeders were also asked about challenges in determining priorities for selection on a 0 to 10 scale $(0=$ very unimportant, $10=$ very important). These challenges were divided into three groups: technical (e.g., lack of consistent or standardized information on genetic materials and methods, limited availability of genetic material), societal (e.g., poor communication with interested parties, separating short-term from long-term needs, difficulty in finding consensus across interested parties), and market-related (e.g., uncertainty if a cultivar being developed would be commercially viable). The third section included questions concerning breeders' ratings of the importance of various fruit traits (on 0 - to 5 -point scale, $0=$ very unimportant, $5=$ very important) and the likelihood breeders would select for each trait (on a 0 to 100 scale, $0=$ lowest likelihood, $100=$ highest likelihood). Given the range of crops and differing horticultural characteristics, we relied on a pre-survey interview with 14 breeders to reduce the traits for each crop to $\approx 50$. In total, there were 77 plant and fruit traits considered in the four rosaceous crops included in this study. In an attempt to reduce the complexity of our analysis, we assessed the relative importance of each individual trait by conducting pairwise comparisons, e.g., juiciness vs. sweetness, sweetness vs. firmness, firmness vs. size, size vs. color, etc. Unfortunately, the analysis was complicated by the large number of individual traits selectable for one each crop. Therefore, we aggregated individual

Table 1. U.S. and Canadian rosaceous breeding programs contacted, survey respondents, and responses used in this study.

\begin{tabular}{lccc}
\hline $\begin{array}{l}\text { Breeding program } \\
\text { main crop }\end{array}$ & $\begin{array}{c}\text { Number of breeding } \\
\text { programs contacted }\end{array}$ & $\begin{array}{c}\text { Number of programs } \\
\text { responding to survey }\end{array}$ & $\begin{array}{c}\text { Number of responses } \\
\text { used in this study }\end{array}$ \\
\hline Apple & 7 & 5 & 4 \\
Apricot & 1 & 1 & - \\
Blackberry & 2 & 2 & - \\
Peach & 13 & 8 & - \\
Pear & 2 & 2 & - \\
Red raspberry & 8 & 5 & 8 \\
Rose & 5 & 2 & - \\
Strawberry & 18 & 11 & - \\
Sweet cherry & 2 & 2 & 24 \\
Tart cherry & 2 & 2 & \\
Total & 60 & 40 & \\
\hline
\end{tabular}

traits for meaningful econometric analysis based on the expert opinion of a breeder using the criterion of similar contributions to fruit or plant characteristics. We refer to these aggregated traits as trait clusters as opposed to individual traits. Table 2 summarizes the nine trait clusters used for analysis: fruit texture, fruit flavor, fruit appearance, biotic resistance, abiotic resistance, plant habit, yield season, postharvest quality, and phytonutrient content.

Econometric model. We used the SAS ${ }^{\circledR}$ TTEST procedure (Cary, NC) to conduct pairwise $t$ tests by crop to identify trait clusters whose mean values differed significantly. We used a double-bounded Tobit model to investigate factors significantly influencing breeders' selection likelihood. A single (pooled) model for the nine trait clusters combined is appropriate when the relationship between the dependent variable and at least some of the independent variables remains the same among different traits. However, this is not the case in this study, because independent variables differ across traits. To decide between the pooled model allowing the intercept to differ across traits and separate models by trait, we conducted the Wald, likelihood ratio, and Lagrange multiplier tests with the null hypothesis favoring the pooled model. Test statistics for each test were 432.4 (Wald), 398.7 (likelihood ratio), and 618.2 (Lagrange multiplier). Thus, the null hypothesis is rejected, suggesting that separate models estimated by trait clusters have higher explanatory power than the pooled model and it is appropriate to model the breeders' selection likelihoods separately by trait clusters.

The double-bounded Tobit model allows censoring in both tails of the probability distribution of the dependent variable. In our particular case, the dependent variable is the likelihood of selection for trait clusters, whose reported values are in the interval ( 0 to 100). The Tobit model follows:

$$
\begin{gathered}
Y= \begin{cases}0 & \text { if } Y^{*} \leq 0 \\
y^{*} & \text { if } 0<Y^{*}<100 \\
100 & \text { if } Y^{*} \geq 100\end{cases} \\
Y_{i}^{*}=X_{i} \beta+\varepsilon_{i}
\end{gathered}
$$

where $Y^{*}$ is a latent variable that is observed for values within the range $(0,100)$ and censored otherwise. $X_{i}$ is the vector of explanatory variables including: (1) ratings for the supply chain considerations influencing breeders' priority; (2) ratings for challenges when determining priorities for selection; (3) years of experience of the breeder leading the program; (4) binary variable for the use of MAB at the breeding program; (5) binary variable for region where the program is located; (6) binary variable for the use of the target crop in the program (fresh or processed market); and (7) binary variable to indicate the main crop in the program. $\beta$ is the vector of parameters to be estimated and $\epsilon_{1}$ represents the error term that captures possibly unobservable factors affecting the likelihood of selection for traits 
Table 2. Individual traits included in each trait cluster.

\begin{tabular}{|c|c|c|c|c|c|c|c|c|}
\hline Texture & Flavor & Appearance & $\begin{array}{l}\text { Disease and pest } \\
\text { resistance }\end{array}$ & $\begin{array}{l}\text { Abiotic } \\
\text { resistance }\end{array}$ & Plant habit & Yield/season & $\begin{array}{l}\text { Postharvest } \\
\text { quality }\end{array}$ & $\begin{array}{l}\text { Phytonutrient } \\
\text { content }\end{array}$ \\
\hline $\begin{array}{l}\text { Fruit } \\
\text { crispness }\end{array}$ & Sweetness & $\begin{array}{l}\text { Flesh } \\
\text { browning }\end{array}$ & Scab & $\begin{array}{l}\text { Resistance to } \\
\text { frost injury }\end{array}$ & $\begin{array}{l}\text { Graft } \\
\text { compatibility }\end{array}$ & $\begin{array}{l}\text { Extended harvest } \\
\text { season }\end{array}$ & Shelf life & $\begin{array}{l}\text { Antioxidant } \\
\text { content }\end{array}$ \\
\hline $\begin{array}{l}\text { Fruit } \\
\text { juiciness }\end{array}$ & $\begin{array}{c}\text { Acid/sugar } \\
\text { balance }\end{array}$ & Flesh color & Fire blight & Winter hardiness & Blind nodes & $\begin{array}{l}\text { Flowering } \\
\text { date }\end{array}$ & $\begin{array}{c}\text { Consistent quality } \\
\text { during storage }\end{array}$ & $\begin{array}{l}\text { Other } \\
\text { phytonutrients }\end{array}$ \\
\hline \multirow[t]{4}{*}{ Seediness } & $\begin{array}{l}\text { Aromatics/ } \\
\text { volatiles }\end{array}$ & Skin color & Aphid & Heat tolerance & $\begin{array}{l}\text { Plant } \\
\text { architecture }\end{array}$ & Productivity & Bruise resistance & \\
\hline & $\begin{array}{l}\text { Titratable } \\
\text { acidity }\end{array}$ & Fruit size & $\begin{array}{l}\text { Other } \\
\text { disease-bacterial }\end{array}$ & & $\begin{array}{l}\text { Pollen } \\
\text { production }\end{array}$ & $\begin{array}{l}\text { Bearing } \\
\text { precocity }\end{array}$ & & \\
\hline & $\mathrm{pH}$ & $\begin{array}{l}\text { Fruit } \\
\quad \text { uniformity }\end{array}$ & $\begin{array}{l}\text { Other } \\
\text { disease- fungal }\end{array}$ & & Self-fertility & & & \\
\hline & & $\begin{array}{l}\text { Surface } \\
\quad \text { texture }\end{array}$ & $\begin{array}{l}\text { Other } \\
\quad \text { disease-viral } \\
\text { Plum curculio }\end{array}$ & & & & & \\
\hline
\end{tabular}

Note: The names of the trait clusters are listed in the header of the table; column contain traits within each cluster.

and is assumed to follow a normal distribution. All parameters were estimated using the QLIM procedure in SAS ${ }^{2}$.

\section{Results}

Table 3 highlights the diversity of rosaceous breeding programs we surveyed based on four parameters: number of crosses per year, number of seedlings produced for screening per year, number of expected new cultivars to be released in the next 5 years, and targeted production regions for each program.

Relative importance of traits. Across crops, the five most important trait clusters were: fruit texture, fruit flavor, postharvest quality, yield/ season, and appearance, but overall the relative importance of trait clusters to breeders varied only slightly (Table 4). Therefore, we focused on the likelihood of selection measure, for which many differences identified by pairwise $t$ tests results are statistically significant (Table 5).

Likelihood of selecting trait clusters. Table 6 presents estimation results of the Tobit model by trait clusters. The dependent variables in Table 6 are the reported likelihoods of selecting for a specific trait cluster with the four crops in the study. Observations are the individual traits for all traits within a cluster. The number of observations ranges from 104 to 274 for the cluster equations. Results from these models provide insight about which factors significantly influence breeders' selection likelihood for each trait cluster and how the impacts of these factors differ across trait clusters. To better explain results, we focus our analysis on five groups of trait clusters: sensory quality (fruit texture, flavor, and appearance), biotic and abiotic resistance, plant production characteristics (plant habit, yield, and harvest season), postharvest quality, and phytonutrient content.

Sensory quality. Across crops, breeders perceived that producers and marketers positively influence the likelihood of selection for fruit texture, whereas wholesalers' influence was negative. Technical challenges like lack of genetic information, lack of genetic material, and deficiency of methods

Table 3. Characteristics of rosaceous breeding programs whose responses were used in this study.

\begin{tabular}{|c|c|c|c|c|}
\hline Program characteristics & Strawberry & Red raspberry & Apple & Peach \\
\hline \multicolumn{5}{|l|}{ Scale of program (crosses per year) } \\
\hline$<5$ & - & - & - & - \\
\hline $6-10$ & - & - & - & 1 \\
\hline $11-20$ & - & 1 & 2 & - \\
\hline $21-30$ & - & - & 2 & - \\
\hline $31-40$ & 1 & 2 & - & - \\
\hline $41-50$ & 1 & - & - & 2 \\
\hline $51-100$ & 4 & 1 & - & 1 \\
\hline $101-150$ & 3 & - & - & — \\
\hline$>150$ & 2 & - & - & 4 \\
\hline \multicolumn{5}{|l|}{ Scale of programs (seedlings produced per year) } \\
\hline$<500$ & - & - & - & - \\
\hline $500-1,000$ & 1 & - & - & 1 \\
\hline $1,001-2,000$ & — & - & - & 1 \\
\hline $2,001-5,000$ & 2 & 3 & 1 & 2 \\
\hline $5,001-10,000$ & 4 & 1 & 2 & 1 \\
\hline $10,001-15,000$ & 2 & - & - & 2 \\
\hline $15,001-20,000$ & 1 & - & 1 & - \\
\hline \multicolumn{5}{|l|}{$20,001-30,000$} \\
\hline$>50,000$ & 1 & - & - & 1 \\
\hline Expected number of cultivars released in 5 years & 45 & 15 & 10 & 39 \\
\hline \multicolumn{5}{|l|}{ Target region } \\
\hline Pacific Northwest & 1 & 1 & 1 & - \\
\hline California & 3 & - & - & 4 \\
\hline Midwest & 1 & - & 1 & - \\
\hline Mid-South & - & - & - & 1 \\
\hline Northeast & 2 & 1 & 1 & - \\
\hline Southeast & 1 & 1 & — & 2 \\
\hline Canada & - & 1 & 1 & 1 \\
\hline Total breeding programs & 8 & 4 & 4 & 8 \\
\hline
\end{tabular}

had a significant negative impact on the selection likelihood of this trait cluster.

Overall, breeders perceived consumers had a positive impact on the likelihood of selection for fruit flavor, whereas producers' impact was negative. This may be because producers are typically paid on grades and standards that do not include flavor, whereas consumers are perceived to value this trait. Market challenges such as high uncertainty for commercial acceptance positively impact the likelihood of selection for flavor. The highest likelihood of selection for flavor occurred in programs in which the breeder had more years of experience, worked in the Southeast and Canada, and worked on red raspberry. Intended use of the crop for processing had a negative significant effect.
Breeders perceived that uncertainty for commercial acceptance had a positive significant impact on the selection likelihood, suggesting breeders believe market risks are reduced by improving flavor characteristics of a cultivar. Only red raspberry breeders had a significant priority for fruit appearance.

Biotic and abiotic resistance. From the breeders' perspective, consumers and marketers had a significant positive impact on the selection likelihood of the trait cluster for biotic stress (disease and pest) resistance, whereas producers' needs had no significant impact. The market challenge, uncertainty if a new cultivar would be commercial viable, positively impacted the likelihood of selection for this trait cluster. In contrast, the societal challenge, poor communication with interested 
Table 4. Importance rating and selection likelihood of trait clusters by crop.

\begin{tabular}{|c|c|c|c|c|c|c|c|c|c|c|c|c|c|}
\hline \multirow[b]{2}{*}{ Trait cluster } & \multirow[b]{2}{*}{ Measure } & \multicolumn{3}{|c|}{ Apple } & \multicolumn{3}{|c|}{ Strawberry } & \multicolumn{3}{|c|}{ Peach } & \multicolumn{3}{|c|}{ Red raspberry } \\
\hline & & Trait rank & Mean & SD & Trait rank & Mean & SD & Trait rank & Mean & SD & Trait rank & Mean & SD \\
\hline Texture & Likelihood & & 89.86 & 14.44 & & 75.79 & 23.76 & & 65.33 & 29.83 & & 67.19 & 27.84 \\
\hline Flavor & Likelihood & & 74.59 & 22.76 & & 70.56 & 30.76 & & 64.15 & 26.62 & & 61.25 & 32.67 \\
\hline \multirow[t]{2}{*}{ Appearance } & Rating & 5 & 3.74 & 0.83 & 5 & 4.05 & 0.90 & 1 & 4.38 & 0.84 & 2 & 4.10 & 1.01 \\
\hline & Likelihood & & 51.21 & 23.43 & & 70.21 & 29.33 & & 77.89 & 21.68 & & 71.23 & 24.37 \\
\hline $\begin{array}{l}\text { Disease and pest } \\
\text { resistance }\end{array}$ & Rating & 8 & 3.33 & 1.26 & 6 & 3.68 & 0.96 & 9 & 3.06 & 1.34 & 6 & 3.59 & 1.10 \\
\hline Abiotic resistance & Likelihood & & 51.00 & 23.00 & & 35.94 & 31.66 & & 50.58 & 31.78 & & 42.70 & 31.91 \\
\hline \multirow[t]{2}{*}{ Plant habit } & Rating & 9 & 3.06 & 1.12 & 7 & 3.62 & 1.08 & 7 & 3.74 & 1.15 & 7 & 3.55 & 1.01 \\
\hline & Likelihood & & 32.39 & 24.39 & & 52.82 & 37.37 & & 55.69 & 34.46 & & 49.77 & 32.28 \\
\hline \multirow[t]{2}{*}{ Yield/season } & Rating & 4 & 3.77 & 0.94 & 2 & 4.41 & 0.75 & 2 & 4.34 & 0.85 & 5 & 3.62 & 1.24 \\
\hline & Likelihood & & 60.76 & 25.49 & & 74.29 & 28.35 & & 79.79 & 20.63 & & 60.50 & 34.84 \\
\hline \multirow[t]{2}{*}{ Post-harvest quality } & Rating & 2 & 4.52 & 0.71 & 1 & 4.44 & 0.89 & 4 & 4.16 & 1.34 & 1 & 4.40 & 0.52 \\
\hline & Likelihood & & 74.84 & 22.75 & & 78.78 & 21.99 & & 64.97 & 31.48 & & 78.60 & 16.75 \\
\hline
\end{tabular}

Table 5. Pairwise comparisons using $t$ tests for likelihood of selection of trait clusters by crop.

\begin{tabular}{|c|c|c|c|c|c|c|c|c|}
\hline \multirow{2}{*}{$\begin{array}{l}\text { Comparison } \\
\text { Texture-flavor }\end{array}$} & \multicolumn{2}{|c|}{ Apple } & \multicolumn{2}{|c|}{ Strawberry } & \multicolumn{2}{|c|}{ Peach } & \multicolumn{2}{|c|}{ Red raspberry } \\
\hline & $15.27^{\mathrm{z}}$ & & 5.23 & & 1.18 & & 5.94 & \\
\hline Texture-appearance & 38.65 & **** & 5.58 & & -12.55 & $* * *$ & -4.04 & \\
\hline Texture-disease and pest resistance & 48.28 & $* * *$ & 22.13 & $* * *$ & 23.89 & $* * *$ & 16.84 & \\
\hline Texture-abiotic resistance & 38.86 & $* * *$ & 39.85 & $* * *$ & 14.76 & & 24.49 & $* * *$ \\
\hline Texture-plant habit & 57.46 & **** & 22.97 & *** & 9.64 & & 17.42 & \\
\hline Texture-yield/season & 29.10 & $* * *$ & 1.50 & & -14.46 & $* * *$ & 6.69 & \\
\hline Texture-postharvest & 15.02 & & -2.99 & & 0.37 & & & \\
\hline Texture-phytonutrient & 39.94 & $* * *$ & 55.66 & *** & 14.10 & & 43.47 & $* * *$ \\
\hline avor-appearaile & 23.37 & $* * *$ & 0.35 & & -13.74 & $* * *$ & & \\
\hline lavor-disease and pest resistance & 33.01 & **** & 16.90 & *** & 22.71 & $* * *$ & & \\
\hline istance & 23.59 & *** & 34.62 & $* * *$ & 13.57 & $* * *$ & 18.55 & *** \\
\hline & & *** & 17.74 & $* * *$ & 8.46 & & & \\
\hline & 13.83 & $* * *$ & -3.73 & & -15.64 & $* * *$ & 0.75 & \\
\hline & -0.25 & & -8.22 & & -0.82 & & 35 & \\
\hline Flavo & 24.67 & $* * *$ & 50.43 & $* * *$ & 12.91 & & & *** \\
\hline and pest resistance & 9.64 & & 16.54 & *** & 36.44 & $* * *$ & & *** \\
\hline & 0.21 & & & *** & 27.31 & $* * *$ & & *** \\
\hline & 18.82 & $* * *$ & 17. & *** & 22.19 & $* * *$ & 1.46 & *** \\
\hline & -9.55 & & 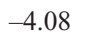 & & -1.90 & & & \\
\hline & -23.63 & $* * *$ & -8.57 & & 12.92 & $* * *$ & -7.37 & \\
\hline Appeara & 1.30 & & 50.08 & *** & 26.65 & $* * *$ & 47.52 & $* * *$ \\
\hline $\begin{array}{l}\text { Disease and pest resistance-abiotic } \\
\text { resistance }\end{array}$ & -9.42 & & 17.72 & $* * *$ & -9.13 & & 7.65 & \\
\hline Disease & & & & & -14.25 & $* * *$ & & \\
\hline & -19.18 & $* * *$ & 20.63 & $* * *$ & -38.35 & $* * *$ & & \\
\hline e and pest resistance-postharvest & -33.26 & $* * *$ & 25.12 & $* * *$ & -23.53 & $* * *$ & -28.25 & *** \\
\hline Disease and pest resistance-phytonutrient & -8.34 & & 33.54 & *** & -9.80 & & 26.63 & *** \\
\hline & 18.61 & $* * *$ & 16. & *** & -5.12 & & & \\
\hline & -9.76 & & 38.35 & $* * *$ & -29.21 & $* * *$ & -17.80 & *** \\
\hline & -23.84 & $* * *$ & 42.8 & $* * *$ & -14.39 & $* * *$ & -35.90 & *** \\
\hline Abiotic & 1.08 & & 15.81 & $* * *$ & -0.66 & & 18.99 & \\
\hline Plant habit-yield/season & -28.37 & $* * *$ & 21.47 & *** & -24.10 & $* * *$ & -10.73 & \\
\hline & -42.45 & $* * *$ & 25.96 & $* * *$ & -9.28 & & -28.83 & *** \\
\hline & -17.52 & & 32.69 & *** & 4.45 & & 26.06 & *** \\
\hline & -14.08 & $* * *$ & -4.49 & & 14.82 & $* * *$ & -18.10 & \\
\hline & & & & $* * *$ & 28.55 & $* * *$ & & *** \\
\hline Postharvest-phytonutrient & 24.92 & $* * *$ & 58.65 & $* * *$ & 13.73 & & 54.89 & *** \\
\hline
\end{tabular}

${ }^{2}$ The values indicate the differences in the means of selection likelihood by crop. A positive value indicates that the first term was rated higher, whereas a negative value indicates that the second term was rated higher importance. For example, texture-flavor 15.27 indicates that the likelihood for selecting texture was 15.27 higher than the likelihood for selecting flavor. Comparisons significant at the 0.05 level are indicated by $* * *$.

parties, decreased the likelihood of selecting for disease and pest resistance. Breeding programs targeting production regions in the Pacific Northwest, Midwest, Northeast, Southeast, and Canada were more likely to select for biotic stress traits, whereas breeders in California were not. This result is not surprising given the reduced biotic stress pressure in West Coast production areas. Breeding programs focused on strawberry and red raspberry as well as fresh market were more likely to select for biotic stress resistance than others.

Overall, breeders placed a positive but not statistically significant emphasis on abiotic resistance, suggesting they believe current levels of resistance are sufficient for producers. Alternatively, this trait cluster may have been so heterogeneous that identification of specific individual traits of importance in specific crops was obscured. Interestingly, only consumers' preferences were found to have a significant positive influence on selection likelihood for the biotic and abiotic resistance. This may reflect a market trend that consumers prefer cultivars that are adapted to the abiotic stresses locally as well as expressing genetic resistance to biotic stresses that reduces the need for pesticides. This agrees with studies stating that consumers, in general, are willing to pay premium prices for produce less exposed to pesticides (Blend and Van Ravenswaay, 1999; Govindasamy and Italia, 1998).

Plant habit and yield season. From the breeders' perspective, the influence of producers' needs on selection likelihood of plant habit was positive but statistically insignificant. The impact of wholesalers' needs was significant and negative. Consumers' preferences significantly increased selection likelihood for plant habit. This result is puzzling, because it would seem producers, rather than consumers, would value cultivars with an improved plant habit. The technical challenges, lack of genetic information, genetic material, and methods significantly lowered likelihood of selection for plant habit. However, breeders facing the societal challenges of distinguishing between short-term and long-term needs placed a high priority on plant habit. This trait cluster was also given high selection likelihood by breeders for targeted production regions in the Northeast and Southeast. By contrast, apple and strawberry breeders were significantly less likely to select this trait cluster.

Both consumers and marketers had a positive and significant influence on the selection likelihood of the trait cluster yield/season, but the impact of producers was insignificant. This result could be attributed to breeders considering that cultivars that have high productivity, extended harvest season, and production consistency have the potential 
Table 6. Estimation results for the Tobit model: likelihood of selection by trait cluster.

\begin{tabular}{|c|c|c|c|c|c|c|c|c|c|}
\hline Variable & Texture & Flavor & Appearance & $\begin{array}{l}\text { Disease and } \\
\text { pest resistance }\end{array}$ & $\begin{array}{l}\text { Abiotic } \\
\text { resistance }\end{array}$ & Plant habit & Yield/season & $\begin{array}{l}\text { Post-harvest } \\
\text { quality }\end{array}$ & $\begin{array}{l}\text { Phytonutrient } \\
\text { content }\end{array}$ \\
\hline \multicolumn{10}{|c|}{ Interested parties } \\
\hline Producers & $15.05 * *$ & $-12.14 * *$ & 5.03 & -3.98 & 0.91 & 4.20 & -7.43 & $14.21 * *$ & $18.26 * * *$ \\
\hline Wholesalers & $-5.99 * *$ & 1.62 & -1.68 & 1.44 & -3.84 & $-7.41 * * *$ & -0.34 & $-5.57 * *$ & $-7.98 * * *$ \\
\hline Marketers & $8.14 *$ & 3.35 & 3.30 & $4.57 *$ & 5.14 & 6.46 & $8.70 * *$ & 3.19 & $8.47 * *$ \\
\hline Retailers & -7.00 & 4.45 & -0.52 & -0.37 & -3.22 & 0.28 & -4.36 & $8.51^{* *}$ & -4.51 \\
\hline Consumers & 3.01 & $10.89 * *$ & 4.33 & $13.75^{* * *}$ & $15.23 * * *$ & $10.53 * *$ & $10.45^{* *}$ & 0.63 & -1.19 \\
\hline Funding agency & 2.88 & -0.03 & 0.20 & 1.02 & -0.32 & 1.58 & 0.06 & $-5.73 * * *$ & $3.71 * *$ \\
\hline Own experience & -0.11 & 1.09 & 0.14 & 2.64 & -4.10 & 1.46 & 2.68 & $8.38^{* *}$ & $12.77^{* *}$ \\
\hline Intended use of crop-processing & -5.10 & $-8.33 * * *$ & -2.98 & $-6.24 * *$ & 3.67 & -3.94 & $-6.30 *$ & $-8.33 * *$ & $-11.52 * *$ \\
\hline \multicolumn{10}{|c|}{ Challenges faced by breeders } \\
\hline $\begin{array}{l}\text { Lack of genetic material, } \\
\text { information, and methods }\end{array}$ & $-7.50 * *$ & -3.29 & -2.49 & -0.57 & 0.10 & $-8.01 * *$ & 1.12 & 4.19 & -5.65 \\
\hline $\begin{array}{l}\text { Poor communication with } \\
\text { interested parties }\end{array}$ & -3.57 & -2.01 & -2.21 & $-4.59 * *$ & 0.64 & -3.20 & $-5.81 * *$ & 2.20 & 1.14 \\
\hline $\begin{array}{l}\text { Separate short-term from } \\
\text { long-term needs }\end{array}$ & 1.68 & -3.24 & -0.85 & 1.97 & 1.08 & $3.94 *$ & 3.05 & -0.80 & -0.30 \\
\hline $\begin{array}{l}\text { Difficult to find consensus across } \\
\text { interested parties }\end{array}$ & 3.20 & -1.31 & -0.94 & -0.51 & -0.81 & 2.30 & -1.28 & -0.06 & $6.48 * * *$ \\
\hline $\begin{array}{l}\text { Uncertainty about commercial } \\
\text { viability }\end{array}$ & 0.70 & $2.81 *$ & $2.96 * *$ & $3.23 * *$ & 1.38 & 2.13 & 2.20 & -0.02 & 2.70 \\
\hline \multicolumn{10}{|c|}{ Breeder leading the program } \\
\hline Years of experience & 0.45 & $1.92 * * *$ & -0.11 & 0.39 & -0.08 & 0.48 & 0.37 & 0.15 & -0.27 \\
\hline \multicolumn{10}{|c|}{ Characteristics of the breeding program } \\
\hline Use of MAB & 10.22 & 8.28 & -8.74 & -0.32 & -20.26 & -0.15 & -8.93 & 19.64 & 25.07 \\
\hline Pacific Northwest & -13.02 & 19.36 & 1.42 & $40.94 * *$ & 8.58 & -0.02 & 30.14 & $85.46^{* * *}$ & -30.01 \\
\hline California & -3.08 & -28.28 & 1.21 & 24.46 & 19.80 & 3.55 & 18.62 & 31.02 & -0.54 \\
\hline Midwest & -41.18 & 1.61 & -9.08 & $38.20 * *$ & -6.98 & 11.81 & -9.14 & $52.91 * *$ & $-50.51 * *$ \\
\hline Northeast & 30.26 & -10.25 & 5.00 & $40.50 * *$ & 34.67 & $36.58 *$ & 23.10 & 18.91 & -3.86 \\
\hline Southeast & 14.85 & $46.70 * * *$ & -2.95 & $54.32 * * *$ & 16.27 & $33.10 *$ & $31.73 *$ & 21.51 & -5.98 \\
\hline Canada & -4.10 & $35.99 * *$ & 14.49 & $57.03 * * *$ & 25.90 & 19.76 & 29.67 & $32.21^{*}$ & $-43.13^{* *}$ \\
\hline \multicolumn{10}{|c|}{ Characteristics of the main crop in the breeding program } \\
\hline Crop is for the fresh market & 3.66 & -10.30 & 10.39 & $25.93 *$ & 9.32 & 10.43 & $27.40 *$ & $39.25 * *$ & $42.12 * *$ \\
\hline Apple & 38.29 & 0.98 & -6.11 & -17.17 & -10.67 & $-36.73 * *$ & -21.96 & -8.38 & $25.06 * *$ \\
\hline Strawberry & -11.08 & 6.29 & -3.30 & $11.02 * *$ & -11.15 & $-22.80 * *$ & 1.78 & $36.00 * * *$ & -11.05 \\
\hline Peach & -5.46 & -4.51 & 9.05 & -6.02 & -0.96 & -6.86 & -3.53 & 0.69 & 6.62 \\
\hline Red raspberry & -6.86 & $19.76 * *$ & $14.71 * *$ & $28.44 * * *$ & 8.72 & -2.53 & 0.24 & $61.30 * * *$ & -9.23 \\
\hline Number of observations & 129.00 & 251.00 & 274.00 & 311.00 & 182.00 & 256.00 & 197.00 & 128.00 & 104.00 \\
\hline
\end{tabular}

$\mathrm{MAB}=$ marker-assisted breeding.

of increasing consumers' satisfaction and consumption because the fruit is of more reliable availability and quality in the market over a longer time window. Excellent progress has been made toward this objective in peach and other tree fruits could similarly benefit. For some of the crops such as strawberry with remontant bloom habit and blackberry and raspberry with primocane fruiting habit, plant habit is critical to getting the extended fruiting season that permits fruit to be available and more affordable to consumers for a longer time window. The impact of intended use of the crop for processing was negative. Breeders of crops for the processed market were less likely to select for traits related to yield/season. The societal challenge, poor communication with interested parties, negatively affected the breeder's selection likelihood for this trait cluster. Breeding programs for targeted production regions in the Southeast were more likely to select this trait cluster.

Postharvest quality. Breeders perceived producers' needs and retailers' feedback and their own experience significantly increasing selection likelihood for this trait cluster, whereas wholesalers' needs and funding agencies had a negative impact. This suggests that according to breeders' viewpoints, producers' needs and retailers' feedback on this specific trait cluster may not be aligned with wholesalers' needs. To analyze contrasting stakeholders' needs was not the focus of this study and more research is needed to investigate further the alignment of priorities. Breeding programs targeting the Pacific Northwest, Midwest, and Canada were more likely to select for postharvest quality as were breeders targeting fresh rather than processing markets. Strawberry and red raspberry breeding programs were more likely to select for postharvest quality, which is not surprising given that these crops are the most perishable of the fruits covered in this study.

Phytonutrient content. From the breeders' perspective, producers' needs, marketers' feedback, funding agencies, and breeders' own experience all had positive and significant impacts on the selection likelihood for phytonutrient content, whereas wholesalers' needs and intended use of the crop for processing had a negative impact. Breeders facing challenges in finding consensus among interested parties were more likely to include this trait cluster. Breeding programs that target production regions in the Midwest and Canada were significantly less likely to select for this trait cluster. Phytonutrient content was given a high priority by breeders targeting the fresh market and by apple breeders particularly.

\section{Discussion}

Given the large number of traits to consider (at least 50 for each crop included in this study), we aggregated individual traits into clusters with related components to facilitate analysis. We found that consumer-driven forces (i.e., consumers, marketers, and retailers) more frequently positively impacted the breeders' likelihood of selection for traits than did producers and the breeder's own experience. Consumers and marketers influenced breeders' decisions on traits for fruit flavor and texture. Unexpectedly, producers' needs did not impact the likelihood of selecting for production-related traits in the biotic and abiotic resistance, plant habit, and yield/season trait clusters.

Technical challenges such as lack of genetic material and information negatively affected the likelihood of selecting for sensory quality and plant habit. Societal challenges such as communication issues and uncertainty about commercial viability had an impact on the likelihood of selecting for the trait clusters biotic and abiotic resistance, yield/season, and phytonutrient content.

Breeding programs targeted toward the fresh market have a higher likelihood of selection for most trait clusters in the study. This result agrees with studies like Richards and Green (2003) suggesting that fresh market crop 
breeders face more challenges in setting priorities than processing market crop breeders.

\section{Conclusions}

A better understanding of what factors influence breeders' priorities and their decisions on trait selection will accelerate the development of cultivars with desirable traits for the entire supply chain and consumers. This study highlights the complex nature of rosaceous breeding and the challenges that breeders face as they focus their efforts in the midst of financial, human, and time resource constraints while still meeting the needs of the entire supply chain. Breeders must consider multiple traits that impact the final fruit product, its profitability, and its production environment. Most of these traits have an interactive, not separate, impact on the final product. Results suggest that using trait clusters rather than the individual traits is a useful approach to simplify the breeders' challenges to assign program priorities. This is not to say that breeders should use an aggregate score for a trait cluster disregarding individual traits, especially in specific crop situations. Our goal was to assess current breeders' priorities from a holistic perspective and discover the clusters breeders are giving more attention to. This initial information will serve to gather a smaller group of individual traits to focus on and include in further studies eliciting values from supply chain stakeholders: producers, shippers, packers, processors, and consumers. Furthermore, our results will allow stakeholder groups and funding agencies to better understand various challenges faced by breeders and to help align priorities with the needs of the entire supply chain. Whether our approach and findings based on this breeder survey are valid will be tested with our future surveys of interested parties in the supply chain. We hope to link trait valuations throughout the supply chain and contribute to a system in which breeding programs and supply chain demands are more intimately and efficiently coordinated.

\section{Literature Cited}

Alpuerto, V.E., G.W. Norton, J. Alwang, and A.M. Ismail. 2009. Economic impact analysis of marker-assisted breeding for tolerance to salinity and phosphorous deficiency in rice. Rev. Agr. Econ. 31:779-792.
Blend, J.R. and E.O. Van Ravenswaay. 1999. Measuring consumer demand for ecolabeled apples. Amer. J. Agr. Econ. 81:1072-1077.

Brown, S.K. 2003. Pome fruit breeding: Progress and prospects. Acta Hort. 622:19-34.

Frey, K.J. 1996. National plant breeding study. I. Human and financial resources devoted to plant breeding research and development in the United States in 1994. Spec. Rpt. 98. Iowa Agr. Home Econ. Expt. Sta., Iowa State Univ. with Coop. State Res., Educ. and Ext. Serv., U.S. Dept. Agr.

Fuglie, K.O. and T.S. Walker. 2001. Economic incentives and resource allocation in U.S. public and private plant breeding. J. Agr. Appl. Econ. 33:459-473.

Fuji, Y., T. Kondo, and F. Osanami. 2007. Quality oriented technical change in Japanese wheat breeding. Proc. Agr. Appl. Econ. Assn. Annu. Mtg., Portland, OR, 29 July to 1 Aug.

Govindasamy, R. and J. Italia. 1998. A willingnessto-purchase comparison of integrated pest management and conventional produce. Agribusiness 14:403-414

Luby, J. and D. Shaw. 2001. Does markerassisted selection make dollars and sense in a fruit breeding program? HortScience 36:872-879.

Richards, T.J. and G.P. Green. 2003. Economic hysteresis in variety selection. J. Agr. Applied Econ. 35:1-14. 